\section{The link between industry and social interests in health in Brazil's National Health Innovation System: the experience of the Brazilian National Institute of Traumatology and Orthopedics (INTO)}

\author{
Articulação entre os interesses produtivos e \\ sociais da saúde no Sistema Nacional de Inovação \\ de Saúde: a experiência do Instituto Nacional de \\ Traumatologia e Ortopedia (INTO)
}

La interrelación entre intereses productivos y sociales en el Sistema Nacional de Innovación de la Salud: la experiencia del Instituto Nacional de Traumatología y Ortopedia (INTO)

\begin{abstract}
This article has two parts. The first discusses the relationship between industry and health interests based on three different but non-mutually exclusive "logics": (a) independent; (b) divergent; and (c) convergent. The second part describes the experience at the Brazilian National Institute of Traumatology and Orthopedics (INTO) with a technology management model. The accumulated expertise in orthopedics at INTO can favor Brazil's domestic medical equipment industry without jeopardizing the country's social health needs. This means directing the production of feasible technologies adapted to the national reality, with a focus on safety and quality, without burdening the public coffers and by overcoming the country's dependency on imported products. The proposal is to promote socioeconomic development through a virtuous circle by attracting reserves and fomenting national competitiveness in domestic and foreign markets while improving social conditions and access to health.
\end{abstract}

Pharmaceutical Technology; Public Policy; Sustainable Development; Innovation
Cid Manso de Mello Vianna 1

Marcelo Kropf Santos Fermam 2

Marcus Paulo da Silva Rodrigues 1

Gabriela Bittencourt Gonzalez Mosegui 3 $\begin{array}{ll}\text { 1. Instituto de Medicina Social, } & \text { Correspondence } \\ \text { Universidade do Estado do } & \text { C. M. M. Vianna } \\ \text { Rio de Janeiro, Rio de Janeiro, } & \text { Departamento de } \\ \text { Brasil. } & \text { Planejamento e } \\ \text { 2 Instituto Nacional de } & \text { Administração, Instituto } \\ \text { Traumatologia e Ortopedia, } & \text { de Medicina Social, } \\ \text { Rio de Janeiro, Brasil. } & \text { Universidade do Estado do } \\ \text { 3 Instituto Saúde Coletiva, } & \text { Rio de Janeiro. } \\ \text { Universidade Federal } & \text { Rua São Francisco Xavier 524, } \\ \text { Fluminense, Niterói, Brasil. } & \text { Rio de Janeiro, RJ 24333-333, } \\ & \text { Brasil. } \\ & \text { cmmv@ims.uerj.br }\end{array}$ 


\section{Introduction}

The living and working conditions of individuals and social groups are closely related to health. What we now call social determinants of health cultural, psychological, ethnic, and socioeconomic factors - affect a specific population's health problems. Meanwhile, health represents a significant share of a society's human capital and thus provides the base for growth in work productivity and generation of wealth.

The poverty-health dyad is thus not dichotomous, but suggests relations within the same sphere of economic and social development. No direct cause-and-effect relationship exists, and countries with high Gross Domestic Product (GDP) per capita do not necessarily boast the best health indicators. The inverse becomes truer as the gap between countries widens, i.e., more severe poverty is associated with worse expected health.

The wide range of societal and individual impacts resulting from an effective intervention makes health a privileged public policy area. Research and innovation in health are critical for promoting social welfare and contributing substantially to poverty eradication and should thus be featured on every country's development agenda 1,2 .

The production process in health itself includes the idea of a social field, linked by different actors in complex networks and systems focused on individual welfare and care. From 2000 to $2011,24 \%$ of the income growth in peripheral countries resulted from the years of life gained through improvements in health systems and investments in innovation in health ${ }^{3}$. Although structuring such production processes requires extensive human, technological, and financial resources and inputs, these alone are incapable of guaranteeing quality of services or even level of care. Thus, although life expectancy has increased by some ten years in many countries, the gap in health between the rich and the poor (whether countries or patients) still persists.

One obstacle to this progress is the lack of technologies and interventions to solve social problems in specific contexts. Research and development investments adjusted to social interests and health priorities remain at dismally inadequate levels, some 1 to $2 \%$ of total research and development (R\&D) in global medical investment ${ }^{4}$. The inherent inequality expressed by lack of access to medical technology must not be taken for granted, but viewed as the material expression of broader social exclusion, resulting mainly from political and economic conditions.
Industry's interests, even when based on intentions and subjectivities focused on the social field, are linked to different relational networks that are not necessarily determined by healthcare. The accumulation of capital in health is associated primarily with the constant inclusion of new healthcare technologies and procedures and only secondarily with users' needs. Lack of access to medicines and other medical technologies cannot be interpreted as a local treatment pattern to provide an ethical justification for reducing or eliminating investment in research.

It is beyond the scope of this article to discuss the definition of health, the complexity of which entails much more than years and quality of life, but one question remains: how to integrate social interests given the population's needs and vulnerabilities vis-à-vis development of the health industry sectors and the interests involved in expanding the industrial base? The answer to this question is essential for defining health as the promotion of equity and universal coverage of healthcare.

This article has two parts. Based on a proposed taxonomy, the first part discusses the perspectives that have correlated the interests of industry policies and health policies. This part concludes with a description of the experience at the Brazilian National Institute of Traumatology and Orthopedics (INTO) in developing a technology management model based on a social vision of health.

\section{Relationship between industry and social interests in health}

\section{Characteristics of technological}

development in the health sector

Until the mid-1970s, the leading companies in the health sector were the large pharmaceutical laboratories, totally integrated, ranging from the discovery of new drugs through clinical development and regulatory, manufacturing, and marketing activities. Innovative drugs with the greatest market potential were discovered by the laboratories themselves, and at least in the early part of this period, they emerged as the result of large-scale "random screening" programs 5 .

Pharmaceutical companies, dominated by "Big Pharma”, forty large highly integrated corporations, extracted their returns from $R \& D$ through a combination of extensive patenting, knowhow, brand names, regulatory entry barriers, and favorable market conditions for their products, largely financed by internal cash flow 6 . 
In the 1980s the pharmaceutical market experienced the significant entry of a new kind of industry, the so-called "biotech companies" 7. Revolutionary scientific discoveries in recombinant genetics and monoclonal antibodies opened new areas of research and dramatically accelerated the pace of basic biomedical scientific discovery in the subsequent decades, making innovation more expensive and more difficult to manage 5 .

Still, competitiveness standards in the pharmaceutical industry have not changed substantially. Currently marketed new drugs follow the same $R \& D$ investment logic as in previous decades, helping to launch new drugs that will guarantee profit and more $R \& D$ investments in the future.

Meanwhile, the medical device industry is highly research-intensive. Companies spend some $9-11 \%$ of their turnover on research and development, second only to the pharmaceutical industry 8 . As the result of competition in the medical device industry, the life cycle of new products is about 18 months, making constant innovation of products an essential condition for survival and maintenance of the companies' competitiveness. As in the pharmaceutical industry, their main challenge is to conceive new ideas, anticipate market demand, manage product development, obtain regulatory approval, and encourage the adoption of new technologies and new generations of existing technologies.

Over time, both industrial and social health factors have been built on discussions involving research, development, and innovation in health on the one hand and ethics, rights, and guaranteed access to quality health services on the other. In this context, two theoretical frameworks have been decisive for understanding how industry and social interests correlate and for establishing policies or mechanisms capable of integrating them: health as a problem of individual choice in the face of market failures or as a fundamental right of all human beings 9 .

In the former, market failures in the health sector are expected to be solved by specific policies that are independent of the companies' interests and that should maximize their global value chain. According to the latter perspective, the interests are incompatible and divergent, and only international agreements can overcome existing barriers. Another more recent approach assumes that health is closely linked to technological development and that health and industrial policies converge in the same objectives.

\section{The independent mode}

The global economy, represented by increasingly fluid circulation of financial and industrial capital, now establishes the capitalist system's order. International expansion of production follows a new logic based on deverticalization of the manufacturing process and subordination of the group's financial decisions.

This means that world trade, investment, and production are increasingly organized around global value chains (GVC), or sets of activities by companies to bring a product to market, ranging from its conception - design, innovation, production, and marketing - to its end use 10. This global system's basic characteristics are: growing interconnection between economic activities that are more fragmented and dispersed; specialization of enterprises and countries in specific functions related to the production chain; world networks of buyers and sellers controlled and coordinated by multinational corporations; and new definitions of productivity and economic performance, intensely affecting the international division of labor and demand for qualification.

This internationalization of production has a fundamental effect on the governance mechanisms exercised by leading corporations. All local decisions, even those related to the market, prices, suppliers, etc., are submitted to the group's international interests, increasing the requirements for coordination of tasks on a global scale and participation in business chains that stimulate technological innovations, learning, and management skills.

National states have also experienced substantial transformations, with a reduction in their regulatory capacity in the new global arena. Local structures are important in the very definition of the GVC subarea in which firms can participate, but the field of social policies is not one of the model's strategic concerns. In fact, consolidation of the production process via GVCs is nothing more than a new representation of the center-periphery scheme in which the difference between productivity and exportation of manufactured products still favors the developed countries.

The technological opportunities currently available in the health sector are unlikely to lead developing economies along a similar path to that of the developed countries. Due to Brazilian industry's low technological intensity, investments in resources for capital-intensive technologies and products and processes in all segments of the industry's value chain are not feasible. The path to pursue would be to reposition local industry to serve Brazil's domestic market and to 
simultaneously become an integrated platform for production and exportation to the GVC 11 .

In this framework, the state has a reduced role as regulator of the economic sphere, where market mechanisms dominate local industrial activities. For example, neither closing the market nor government purchasing power has the capacity to make the domestic industrial sector more competitive, productive, andinternationalized 12 .

Meanwhile, the state does not need to forfeit its regulatory role. It should pursue a policy that promotes regulatory convergence and considers and serves global markets, based on economic development and industrial modernization 11 . The regulatory process should also help health sector companies overcome the existing barriers to exportation, especially to the developed countries.

In this scenario, the structural foreign trade deficit is the product of an inconsistent and relatively weak policy on the part of the Brazilian government. There are no incentives for industries to focus on GVC niches where they might have global competitive advantages, rather preferring to concentrate on the domestic market ${ }^{13}$. An industrial policy targeting the GVC could, for example, contribute to decreasing the trade deficit in the medical equipment sector.

According to this view, health policy is developed in another field. The dynamism and logic of industrial development lie outside national borders. Although correlated, health and industrial policies can follow their own paths. Industry can engage in one or several GVC, independently of the health problems circumscribed within local needs 11 .

\section{The divergent model}

The divergent model assumes that most medical technologies are developed as "global public health products", i.e., as available, accessible, and affordable goods for the world population's health needs. Meanwhile, the existence of a clear public health need does not necessarily translate into a demand for new products. 3 Distinct logics inevitably emerge when questioning whether the development of any and all medical technologies should be oriented exclusively towards profit.

Besides, where the private sector does not glimpse a clear commercial interest, it does not run the risk of developing a product to meet such a need. Consequently, $80 \%$ of industry's financing, which defines the better part of the research agenda, is guided more by marketing than by clinical considerations 14 .

An inevitable conclusion is that the health sector's interests often diverge from those of industry, centered on future profits. Given the profit motive (the central focus of industrial activities), the following general question emerges: is there some solution to the inevitable conflict of interests between private companies and public health?

One proposed solution is public-private agreements that foster research and the generation of social- interest technologies. The proposal is to create "market" conditions through financial incentives plus multi-sector agreements between governments, industry, funding agencies, etc. Such partnerships include the for-profit private sector (pharmaceutical companies) and not-forprofit organizations (philanthropic institutions and foundations), international aid and development agencies, governments, and universities. A classic example of such an agreement between public and private institutions was the production of the antimalarial drug melfloquine. Initially discovered by the Walter Reed Army Institute of Research, it was later developed in partnership between industry and TDR (the World Health Organization Special Program for Research and Training in Tropical Diseases) 15.

This kind of approach is still current and expanding. In the specific case of malaria, HIV/ AIDS, tuberculosis, and other diseases associated with poverty, the approach become an international challenge as part of the Millennium Development Goals 3 . The proposal elaborated by the United Nations demonstrates the influence of global agendas on priority-setting and the window of opportunities for investments by countries or through bilateral or multilateral agreements 16 .

The model of social risk capital, with a focus on specific diseases (e.g., malaria and tuberculosis) and financed by philanthropic institutions and development agencies from the developed countries, has been a key instrument for involving the pharmaceutical industry in technological development projects 16 . Heightened efforts in research and development (R\&D) for these diseases have led to the appearance and introduction of important new interventions in the last two decades. The resulting technologies have had a strong impact by decreasing and in some cases even reversing the spread of these epidemics in low and middle-income countries. However, participation by industry is limited and often focused on a small number of projects for discovering new drugs.

One strategy is to recreate market conditions for the industrial sector, like the legislation on orphan drugs in the United States, combining fewer taxes, exclusive market rights, and patent protection 15 . Although potentially feasible, this 
strategy has obvious limitations and is not applicable across the board.

Another proposed strategy, mainly in the vaccines market, is to set tiered prices for developed and developing countries. The aim is that the cost of research for new drugs be covered by the industrialized nations in order to allow lower prices, as the result of the production cost plus a "social" profit margin in the poorer countries 17. Although this mechanism may be useful in specific situations, it would be hard to apply to neglected diseases that exist mainly in poor countries.

Unlike the previous model, social interests remain a concern for various economic agents, although limited to specific projects. In addition, the industrial sector is frequently called into partnerships with universities, Nongovernmental Organizations (NGOs), and the public sector.

\section{The convergent model}

A universal health system consists not only of the demand for goods and services, but also of the manufacturing base that lends sustainability to health policy. Social development is directly interconnected with the competitiveness of national health industries.

The state's absence in the innovation process leads to a transfer of responsibility to the private sector, increasing the polarization between the social and economic dimensions in the health system. There is no inherent contradiction between these dimensions, but weakness of the latter, which prevents the former from reaching its objectives.

The potentially profound impacts of an effective health intervention make it a privileged space for public policy, and which should not be forfeited by the state. Contrary to the previous social risk model, in which the public sector bears a portion of the expectation for financial return, in this scenario the Health Economic-Industrial Complex (HEIC) should be seen as one of the strategic areas in industrial policy. In addition, no expectation exists as to participation by international institutions and NGOs in the consolidation of the industrial sector.

How can the development of products with high social value be encouraged? Based on the concept of a National System of Innovation in Health (NSIH) 18, the HEIC has the capacity to surmount the dichotomy between industry and health interests. The public-private institutionality of the HEIC opens a window of opportunity for strengthening the process of generating innovation in health, given the state's important role.
Health's socioeconomic dimension involves a systemic understanding, highlighting government's role as provider of health as a social, democratic, and universal right, a characteristic element of the Welfare State 19. According to the concept, the industrial base in health is responsible for the economic dynamism that raises health to the level of strategic component in national development. This large system of production and services provision, promoted and regulated by the state, has been defined as the health economic and industrial complex 20.

It is necessary to understand the heart of the HEIC as a system capable of developing the economy without abandoning social logic. Otherwise, the essence is lost as a policy for socioeconomic development and innovation in health. The social and economic components of health are inseparable, despite an outdated (but persistent) logic and mindset that see health as merely a marketable good.

There is thus legitimate concern towards hasty and accelerated incorporation of technologies by health services, i.e., before the consolidation of a robust and competitive industrial park. The pressure brought to bear by technological progress in its current form is inconsistent with the maintenance of a universal system. This technological development requires urgent orientation to make it more equitable and capable of reversing the prevailing dynamic of generating innovation dissociated from social needs. The big question in this context is how to induce the pace and define the direction of technical progress, i.e., for new technologies to lead the health system to socially desirable and sustainable goals 21 .

It is imperious to avoid the risks that lead the health sector into a vicious circle of dependency, backwardness, iniquity, and an industrial structure with limited dynamics. This problem can jeopardize health's strategic participation in Brazil's development policy agenda, undermining the national industrial base and consequently aggravating social determinants of health that prevent strengthening of the Brazilian Unified National Health System (SUS).

Public healthcare services can play a strategic role in this context, given the challenges of health promotion and maintenance and the need to strengthen the HEIC. The latter is systemic in nature, given the role of the industrial base in consuming and demanding health technologies. In fact, the hospital sector accounts for the leading share of the health services sector in terms of demand, thereby helping avoid idle industrial capacity.

The recent organization of the public health services subsystem has occupied an outstanding 
position in the social dimension of innovation in health, which highlights and approaches it to the convergent model of relationship between industry and social interests in health. Brazil's federal hospitals, especially the national institutes belonging to the medium and high-complexity healthcare network, play a fundamental role in the innovation dynamics of the HEIC 22, based on both the orientation of the installed domestic capacity of the health industry sectors and the possibility of formulating policies that link industry and social interests in health.

Strengthening the NSIH has meant a paradigm shift in Brazil's federal hospitals, especially the National Institutes, which have expanded their autonomy vis-à-vis the Brazilian Ministry of Health, principally in relation to their public procurement policies and technical and scientific capabilities. The great majority of the National Institutes have grown around their technological capabilities, built through their healthcare record with government investments, teaching, research, and development of new products and services.

These national institutes of innovation in health are increasingly involved in the underlying mechanisms of innovation focused on the population's welfare, through teaching research, development, and formulation or participation in public healthcare policies. The various university hospitals belong to these national institutes and are responsible for research and training of health professionals all across the country, creating what we call the "hospital network for innovation in health".

Given the above, with the aim of illustrating and characterizing the hospital sector's actual participation according to the convergent model, we present the last two years' efforts by the INTO in research, development, and innovation. The coexistence of the industry and social interests focuses on the real interest that should prevail in health: to guarantee social welfare without jeopardizing economic development.

Finally, we emphasize that this convergent model of linking industrial and social interests simply underscores the concept of innovation as generating not only commercial but also social value by tying production and economic development to health and welfare. The importance of the convergent model for health becomes clear, based on the premise that the institutional mission, vision, and values of any hospital involves the provision of effective, safe, and high-quality services aimed ultimately at health promotion.

This model for linking industrial and social interests is clearly present in other countries around the world, since hospitals are famous as a leading sector in the production and innovation of health technologies. For example, according to a study on technological trends in orthopedic prostheses by the innovation management division of the INTO, which will be presented in the following section of this paper, 333 patents were filed from 2000 to 2014 by hospitals and clinics in countries like the United States, China, France, Korea, and Russia, and $30 \%$ of these patent applications were submitted by hospitals in partnership with universities 23 .

These data stand out because the prevailing healthcare logic in Brazil has criticized any evidence of the industrial and economic system aligning health with commerce. The convergent model potentially stands out from other models by combining distinct interests that justify themselves, i.e., the production of innovations in goods to guarantee society's health and disseminate social policies calling for better access to state-of-the-art technologies at more affordable prices.

\section{A case of innovation in health: INTO - from innovation in management and research to patient care}

\section{Brief history}

The INTO was founded in late 1994 under the coordination of the Healthcare Secretariat of the Brazilian Ministry of Health. The Institute has 38 consulting rooms, 255 inpatient beds, 48 intensive care beds, and 21 operating rooms. In the year 2013 there were 208,217 outpatient consultations, 17,351 medical consultations, and 9,959 surgeries. Hospital mortality was extremely low $(0.48 \%)$, and mean length-of-stay was 7.6 days.

In teaching and research, the INTO is an accredited teaching hospital and offers medical residency in orthopedics and traumatology, nursing, and pharmacy. INTO currently offers three lines of research: (1) prophylactic, diagnostic, and therapeutic methods applied to the musculoskeletal system; (2) effort and performance of the musculoskeletal system; and (3) translational research applied to the musculoskeletal system.

\section{$\underline{\text { Innovation consultancy }}$}

As a way of aligning the healthcare services platform with the logic of the health economic and industrial complex, INTO recently innovated in management by creating a division in charge of advising the institute's staff members on issues involving technological innovation. 
Linked directly to the Coordination of Special Programs (Copes), the division in charge of institutional development, among other activities, the Advisory Division on Innovation of the Coordination of Special Programs (Ascopes), launched its activities on May 6, 2013, beginning with a permanent project for stimulating innovation in health called the Inova-INTO Project. The project represents an institutional growth strategy based on the development of innovation and aimed at expanding health research to improve access to patient care for the Brazilian population.

Inova-INTO includes three permanent work phases. The first identifies the competencies for innovation (present as person skills), based on all the staff members' professional training. This phase collects each sector's essential competencies and incentivizes innovative ideas. The second phase maps these competencies and does a prior study on the feasibility and potential for innovation in the existing or embryonic ideas, projects, and research. The third and final phase is the establishment of internal research, development, and innovation groups that may or may not have external partnerships (public or private). These partnerships are established between INTO and the other institution via an agreement for technical cooperation in the case of patent applications, articles, and exploring innovation rights and financing.

There are various projects under way and others that have been finalized. One of the leading projects is a study on technological trends in orthopedic prostheses, aimed at orienting research, development, and production of modern prostheses. The study analyzes the potential of innovations in orthopedic implants in the international scenario. The aim is to identify new concepts for orthopedic medicine and economic development through health. Based on this premise, the concepts of technological forecasting of patents and scientific articles are used to foresee trends in orthopedic implants and thus seek Brazil's positioning vis-à-vis technological knowledge in orthopedic devices in the future.

Osteoarthritis is known to be the leading cause of total or partial joint loss 24 . Osteoarthritis presents as a progressive clinical condition evolving with functional limitation and incapacity due to pain, decreased range of motion, stiffness, and muscle weakness. When drug treatment fails to contain joint and bone degeneration, arthroplasty is indicated for joint replacement with prostheses 25 .

The advanced materials used to produce prostheses are called "biomaterials", and their concept varies greatly. Briefly, they are materials aimed at an interface with the biological systems to assess, treat, augment, or replace any body tissue, organ, or function. Their evolution is relatively recent, and the fusion of biotechnologies with nanotechnologies will have an unparalleled range of applications and impacts in a huge market, estimated at US\$ 1 trillion 26.

The emerging concept of "technological forecasting" thus applies to studies aimed at anticipating and understanding the potentialities, evolution, characteristics, and effects of technological innovations, particularly their invention, innovation, adoption, and use 27 . Technological forecasting analyzes the life cycle of technologies in the present in order to understand them in the future, with their short, medium, and longterm social, political, and economic implications throughout this process. The aim is to identify strategic areas of research and emerging technologies capable of generating economic and social benefits.

Anticipation of technological advancements can reduce possible dependencies by pursuing strategic positioning that influences and orients technological paths in the future. This evolutionist process means launching ahead and guaranteeing the competitiveness and survival of the various actors comprising a country's national innovation system.

Research on new orthopedic prostheses by the advisory division on innovation at INTO intends to analyze the scientific and technological evidence that can yield possible health benefits and that justifies and orients $R \& D$ investments in Brazil. This strategy means planning the development of new orthopedic implants with the desirable characteristics for these devices in the future, drawing on the history of growth in the Brazilian healthcare sector in recent decades.

The production of new prostheses in Brazil creates great possibilities and expands the country's economic and social opportunities by reducing the trade deficit resulting from the importation of prostheses and the biomaterials used in such equipment, expenditures by the SUS with surgeries and readmissions to hospital for evaluation and replacement of prostheses, optimization of waiting time for implants, reduction of inherent problems in orthopedic diseases that can cause extenuating pain, and minimization of sick leave and social security costs, while improving the population's welfare, especially in the future scenario of post-2030 demographic transition. 


\section{Conclusion}

Health cannot exist without investment in health. Technological progress and innovation in health provide a secure base for achieving better living conditions for the population. When such innovations focus on solving social problems, the impact is to decrease social exclusion. While the focus is often on the structural and technical reforms needed to propel industry's competitiveness, the definitive inspiration for innovation in health should be patients and their needs for social inclusion.

This study aimed to explore the relations between industrial and social interests in health. The attempt was to understand how social interests related to the population's needs and vulnerabilities could (or should) be integrated into the development of the health industrial sector and the interests in expanding the industrial base. For this purpose, we proposed a taxonomy that seeks to explain the correlation of these interests based on three distinct logics, called "independent", "divergent", and "convergent". Industrial and technological policies for innovation in the health sector have been developed by national states and multilateral agencies based on the conceptualization of how these interests interact with each other.

\section{Contributors}

C. M. M. Vianna , M. K. S. Fermam , M. P. S. Rodrigues and G. B. G. Mosegui participated in the article design and all stages of production and were responsible for drafting the final version.
In recent years, Brazil has witnessed the consolidation of the idea that industrial and social interests converge and can create a virtuous circle for solving health problems. This context requires pursuing the convergent view of social and economic development, by which the state should play its political role as the link in technological and social development 28 .

The knowledge produced in orthopedics at the National Institute of Traumatology and Orthopedics can favor the national medical equipment industry without abandoning Brazil's social health needs. That is, it can orient the production of feasible technologies adapted to Brazil's national reality, with a focus on safety and quality without burdening the public coffers or abandoning reliance on imported products. This is a challenging mission, but it cannot be neglected, since socioeconomic development should be a virtuous circle, attracting revenues by fomenting national competitiveness in domestic and foreign markets, generating jobs and improving social conditions and access to health.

\section{Acknowledgments}

To Fiocruz for the financial support. 
1. Organização Pan-Americana da Saúde, Organização Mundial da Saúde. 138a Sessão do Comitê Executivo. Resolução CE138.R19: Agenda de saúde para as Américas 2008-2017. Washington DC: Organização Pan-Americana da Saúde; 2006.

2. Organização Pan-Americana da Saúde. Plano estratégico da Organização Pan-Americana da Saúde 2014-2019. Washington DC: Organização Pan-Americana da Saúde; 2013.

3. Path WC, Christenson K. The role of research and innovation for health in the post-2015 development agenda bridging the divide between the richest and poorest within a generation. Washington DC: Council on Health Research for Development/ International AIDS Vaccine Initiate; 2014.

4. Jamison DT, Summers LH, Alleyne G, Arrow KJ, Berkley S, Binagwaho A, et al. Global health 2035: a world converging within a generation. Lancet 2013; 382:1898-955.

5. Cockburn IM. The changing structure of the pharmaceutical industry. Health Aff (Millwood) 2004; 23:10-22.

6 Grabowski H, Vernon J. The determinants of pharmaceutical research and development expenditures. J Econ Issues 2000; 10:201-15.

7. Zucker LG, Darby MR, Brewer MB. Intellectual human capital and the birth of U.S. biotechnology enterprises. Am Econ Rev 1998; 88:290-306.

8. Chatterji AK, Fabrizio KR, Mitchell W, Schulman KA. Physician-industry cooperation in the medical device industry. Health Aff (Millwood) 2008; 27:1532-43.

9. Edwards RT. Paradigms and research programmes: is it time to move from health care economics to health economics? Health Econ 2001; 10:635-49.

10. Organization for Economic Co-operation and Development. Interconnected economies: benefiting from global value chains. Synthesis report. http://www.oecd.org/sti/ind/interconnectedeconomies-GVCs-synthesis.pdf (accessed on 28/ Oct/2014)

11. Centro Brasileiro de Relações Internacionais. Convergência regulatória, cadeias globais e o desenvolvimento da indústria de saúde no Brasil: o setor de equipamentos médicos em uma análise regional. Rio de Janeiro: Centro Brasileiro de Relações Internacionais; 2013.

12. Sperancini JHBS, Cappa J, Onusic LM, Ganaka CTS, Silva LF. Do conteúdo local à cadeia global de valores: políticas para o complexo industrial da saúde. In: XV Congresso Latino-Iberoamericano de Gestão de Tecnologia. http://www.altec2013. org/programme_pdf/800.pdf (accessed on 17/ Nov/2014).
13. Confederação Nacional da Indústria. Brazilian manufacturing in international perspective: a global value chain analysis of Brazil's aerospace, medical devices, and electronics industries. http://www.cggc.duke.edu/pdfs/CNI_Brazil_ GVC_Report_Final_2013-09-05.pdf (accessed on 21/Nov/2014).

14. European Commission. Innovation in health care, from research to market to health-systems to patient. Main conclusions from 2010, 2011, 2012 conferences. http://ec.europa.eu/research/health/ pdf/innovation-in-healthcare-overview-report_ en.pdf (accessed on 22/Aug/2013).

15. Trouiller P, Olliaro P, Torreele E, Arbinski J, Laing R, Ford N. Drug development for neglected diseases: a deficient market and a public-health policy failure. Lancet 2002; 359:2188-94.

16. Wheeler C, Berkley S. Initial lessons from publicprivate partnerships in drug and vaccine development. Bull World Health Organ 2001; 79:728-34.

17. Haddar M. La mutation du marché mondial des vaccins. La Revue Préscrire 1995; 15:844-7.

18. Gadelha CAG, Quental C, Fiallho BC. Saúde e inovação: uma abordagem sistêmica das indústrias da saúde. Cad Saúde Pública 2003; 19:47-59.

19. Gadelha CAG, Costa LS, Maldonado J. O complexo econômico-industrial da saúde e a dimensão social e econômica do desenvolvimento. Rev Saúde Pública 2012; 46 Suppl 1:21-8.

20. Gadelha CAG. O complexo industrial da saúde e a necessidade de um enfoque dinâmico na economia da saúde. Ciênc Saúde Coletiva 2003; 8:521-35.

21. Fundação Oswaldo Cruz. A saúde no Brasil em 2030: diretrizes para a prospecção estratégica do sistema de saúde brasileiro. Rio de Janeiro: Fundação Oswaldo Cruz/Instituto de Pesquisa Econômica Aplicada/Ministério da Saúde/Secretaria de Assuntos Estratégicos da Presidência da República; 2012.

22. Botelho AJJ, Alves AS. As lacunas de inovação em saúde no Brasil: entre a produção de ciência e a tecnologia na saúde. In: Costa LS, Bahia L, Gadelha CAG, organizadores. Saúde, desenvolvimento e inovação. v. 1. Rio de Janeiro: CEPESC Editora; 2015. p. 270-310.

23. Kropf M. Tendências da pesquisa e desenvolvimento em próteses ortopédicas [Tese de Doutorado]. Rio de Janeiro: Programa de Pós-graduação em Tecnologia de Processos Químicos e Bioquímicos, Escola de Química, Universidade Federal do Rio de Janeiro; 2015.

24. Salmela LFT, Macedo BG, Aguiar CM, Bahia LA. O impacto da movimentação passiva contínua no tratamento de pacientes submetidos a artroplastia total de joelho. Acta Fisiátrica 2003; 10:21-7. 
25. Hochberg MC, Perlmutter DL, Hudson JI, Altman RD. Preferences in the management of osteoarthritis of the hip and knee: results of a survey of community-based rheumatologists in the United States. Arthritis Care Res 1996; 9:170-6.

26. Matsui M. Correlações entre estrutura química, superestrutura macromolecular e morfologia das blendas e redes poliméricas à base de quitina e poliuretano [Doctoral Dissertation]. Curitiba: Programa de Pós-graduação em Engenharia, Universidade Federal do Paraná; 2007.

\section{Resumo}

Este artigo está dividido em duas partes. Na primeira discute-se como se relacionam os interesses produtivos e a saúde a partir de três "lógicas" ou perspectivas diferentes que não são mutuamente excludentes: (a) independente; (b) divergente e (c) convergente. Na segunda, descreve-se a experiência do Instituto Nacional de Traumatologia e Ortopedia (INTO) na montagem de um modelo de gestão de tecnologia. O conhecimento internalizado em ortopedia do INTO pode favorecer a indústria nacional de equipamentos médicos sem abandonar as necessidades sociais brasileiras de saúde. Isto é, direcionar a produção de tecnologias viáveis e adaptadas à realidade nacional, com foco em segurança e qualidade, sem onerar os cofres públicos e abandonando a dependência de produtos importados. A proposta é a de promover um desenvolvimento socioeconômico que construa um ciclo virtuoso, por atrair divisas e fomentar a competitividade nacional em mercados internos e externos, melhorando as condições sociais e de acesso à saúde.

Tecnologia Farmacêutica; Política Social; Desenvolvimento Sustentável; Inovação
27. Coates V, Farooque M, Klavans R, Lapid K, Linstone HA, Pistorius C, et al. On the future of technological foresight. Technol Forecast Soc Change 2001; 67:1-17.

28. Costa, LS, Bahia L, Gadelha CAG. Pensar desenvolvimento e saúde no Brasil. In: Costa LS, Bahia L, Gadelha CAG, organizadores. Saúde, desenvolvimento e inovação. v. 1. Rio de Janeiro: CEPESC Editora; 2015. p. 17-42.

\section{Resumen}

Este artículo está dividido en dos partes. En la primera, se discute cómo se relacionan los intereses productivos y la salud, a partir de tres "lógicas" o perspectivas diferentes, que no son mutuamente excluyentes: (a) independiente; (b) divergente; (c) convergente. En la segunda, se describe la experiencia del Instituto Nacional de Traumatología y Ortopedia (INTO) en el montaje de un modelo de gestión de tecnología. El conocimiento internalizado en ortopedia del INTO puede favorecer la industria nacional de equipos médicos, sin abandonar las necesidades sociales brasileñas en salud. Esto es, dirigir la producción de tecnologías viables y adaptadas a la realidad nacional, centrándose en la seguridad y calidad, sin ser onerosos para el erario público y abandonando la dependencia de productos importados. La propuesta es promover un progreso socioeconómico que construya un ciclo virtuoso, con el fin de atraer divisas y fomentar la competitividad nacional en mercados internos y externos, mejorando las condiciones sociales y de acceso a la salud.

Tecnología Farmacéutica; Política Social; Desarrollo Sostenible; Innovación
Submitted on 16/Dec/2014

Final version resubmitted 20/Oct/2015

Approved on 22/Oct/2015 